\title{
Estimates of the Replacement Costs of Commercial and Backyard Avocado Trees in South Florida ${ }^{1}$
}

Edward A. Evans and Jonathan H. Crane ${ }^{2}$

\section{Introduction}

The Florida avocado industry is the state's second-largest fruit industry (behind citrus) and is worth $\$ 12$ to $\$ 14$ million a year at the farm gate (USDA/NASS 2008) and \$30 million at the wholesale level (Brooks, personal communication). The commercial avocado industry in Florida consists of approximately 7,500 acres ( 60 percent of the total tropical fruit crop acreage), about 951 growers (USDA/NASS 2008; USDA/NASS 2009; Crane, Balerdi, and Maguire 2007), and 35 registered avocado handlers and shippers (Brooks, personal communication). Of these 7,500 acres, over 98 percent are located in southwest Miami-Dade County. In addition to commercial production, many homeowners in South Florida have backyard avocado trees. These trees form an important part of the urban canopy and contribute economic, aesthetic, and environmental benefits, adding as much as 10 percent to residential property values. They provide shade and wildlife habitat, and improve air quality. As pointed out by McAliney (1993), a single mature tree can absorb carbon dioxide at a rate of 48 pounds per year, and release enough oxygen back into the atmosphere to support two human beings. It is estimated that there are more than 250,000 backyard avocado trees scattered across Miami-Dade County (Pybas, personal communication).

In light of the recent discovery of the redbay-laurel wilt disease complex, which can destroy both commercial and backyard avocado trees (Mayfield et al. 2008), the purpose of this article is to estimate how much it would cost to replace all commercial and residential backyard avocado trees in Miami-Dade, Broward, Palm Beach, and Lee Counties.

\section{Methodology}

Although there are several approaches to estimating the replacement cost, the approach adopted in this article is based on compensatory value (Nowak et al. 2002); that is, the value owners should be compensated for the loss of mature avocado trees, based on the principle that avocado trees can be viewed as structural assets. The compensatory value of the trees is calculated using the internet tool Tree Value Analysis (Evans et al. 2006). Calculations are based on the present value of the net costs of

1. This is EDIS document FE825, a publication of the Food and Resource Economics Department, Florida Cooperative Extension Service, Institute of Food and Agricultural Sciences, University of Florida, Gainesville, FL. Published December 2009. Please visit the EDIS website at http://edis.ifas.ufl.edu.

2. Edward A. Evans, assistant professor, Food and Resource Economics Department, University of Florida, Tropical Research and Education Center, Homestead, FL, and Jonathan H. Crane, professor, Horticultural Sciences Department, University of Florida, Tropical Research and Education Center, Homestead, FL, Florida Cooperative Extension Service, Institute of Food and Agricultural Sciences, University of Florida, Gainesville, FL. 
replacing lost trees and nurturing replacement trees to the production equivalent of lost trees. Net costs include: (1) the cost of replacing trees (stump removal, land preparation, purchasing and planting new trees); (2) new tree cultivation costs (fertilizer, pruning, weeding) during a replacement period of seven years; and (3) lost revenue from non-bearing trees. Stream of net costs for bringing replacement trees up to the production equivalent of lost trees are discounted to determine the present value of a tree.

Using the tool and inserting a $\$ 0.25$ per pound farm gate price, the 2007/08 average grower's price (USDA/NASS 2009), a $\$ 150$ per tree stump removal cost (Evans 2006), and a five percent discount rate, we estimate the value of a mature tree to be around $\$ 330$. This value was used for both commercial and non-commercial avocado trees and does not include any provisions for sentimental values attached to a homeowner's tree, or the fact that inputs used by the homeowner, including fertilizer and water, could be far more expensive than those used by commercial producers. In the case of commercial orchards, an average of 87 trees per acre was used to estimate the total number of trees in a county (Balerdi, personal communication)

To estimate the total number of backyard trees in Broward, Palm Beach, and Lee Counties, it was assumed that the ratio of backyard trees to population that exists in Miami-Dade County would be the same in these counties. This ratio was then applied to population estimates of these counties as contained in the 2008 United States Census.

\section{Results}

The table below summarizes the results of the cost analysis. The figures indicate that the total cost to replace all avocado trees in the four counties is $\$ 422.8$ million. The cost to replace only the commercial trees is estimated at $\$ 216.1$ million, while the cost for residential backyard trees is $\$ 206.7$ million. As expected, Miami-Dade County had the highest total replacement cost of \$294.9 million, followed by Broward County at $\$ 60.5$ million.

\section{Conclusions}

Avocado trees contribute several market (food source, income, and employment) and nonmarket (open space retention, canopy cover, carbon sequestration, and wildlife habitats) benefits. The importance of canopy cover is recognized by the counties as evidenced by the Adopt-A-Tree Program, which has distributed about 13,822 avocado trees to date. Redbay laurel wilt disease complex has spread to South Florida, where the cost to replace avocado trees destroyed by this disease in Miami-Dade, Broward, Palm Beach, and Lee Counties would be about $\$ 423$ million. As our analysis shows, it is imperative to prevent the spread of this disease in Florida.

\section{References}

Brooks, P. 2009. Personal communications, Miami, FL.

Crane, J.H., C.F. Balerdi, and I. Maguire. 2007. Avocado growing in the Florida home landscape (Circular 1034). Electronic Data Information Source (EDIS) MG213. Horticultural Sciences Department, University of Florida, Gainesville, FL. $\underline{\text { http://edis.ifas.ufl.edu/MG213 }}$

Evans, E., C. Balerdi, J. Crane, and S. Nalampang. 2006. Determining the value of an orchard tree. Electronic Data Information Source (EDIS) FE676. Food and Resource Economics Department, University of Florida, Gainesville, FL. http://edis.ifas.ufl.edu/FE676

Mayfield, A., J. Crane, and J. Smith. 2006. Laurel Wilt: A threat to redbay, avocado, and related trees in urban and rural landscapes. Electronic Data Information Source (EDIS) HS1137 Horticultural Sciences Department, University of Florida, Gainesville, FL. http://edis.ifas.ufl.edu/HS391

McAliney, M. 1993. Arguments for Land Conservation: Documentation and Information Sources for Land Resources Protection. Sacramento, CA: Trust for Public Land.

Nowak, D., D. Crane, and J. Dwyer. 2002. Compensatory value of urban trees in the United States. Journal of Arboriculture 28(4): 194-199. 
Pybas, D. 2009. Personal communications, Miami, FL.

U.S. Census. 2008. United States Census

Bureau, Washington, D.C.

http://factfinder.census.gov/servlet/

DatasetMainPageServlet?_program=PEP\&_submenuI

$\underline{\mathrm{D}=\text { datasets_1\&_lang }=\text { en\&_ts }=}$

USDA/NASS. 2008. Non-Citrus Fruits and

Nuts: 2008 Preliminary Summary, Fr Nt 1-3 (09)a.

United States Department of Agriculture, National

Agricultural Statistic Service, Washington, D.C.

(May 22).

http://usda.mannlib.cornell.edu/usda/nass/

NoncFruiNu//2000s/2009/NoncFruiNu-01-23-

2009_revision.pdf

USDA/NASS. 2009. Census of Agriculture, Florida - State and County Data, Volume 1: Graphic

Area Series, Part 9. United States Department of Agriculture, National Agricultural Statistics Service, Washington, D.C. (April).

http://www.agcensus.usda.gov/Publications/2007/

Full_Report/Volume_1,_Chapter_1_State_Level/

$\underline{\text { Florida/flv1.pdf }}$ 
Estimates of the Replacement Costs of Commercial and Backyard Avocado Trees in South....

Table 1. Replacement cost based on value of avocado trees. *

\begin{tabular}{|c|c|c|c|c|c|c|}
\hline & Unit & $\begin{array}{r}\text { Miami-Dade } \\
\text { County }\end{array}$ & $\begin{array}{l}\text { Broward } \\
\text { County }\end{array}$ & $\begin{array}{r}\text { Palm Beach } \\
\text { County }\end{array}$ & $\begin{array}{l}\text { Lee } \\
\text { County }\end{array}$ & Total \\
\hline $\begin{array}{l}\text { Value of commercial } \\
\text { trees }\end{array}$ & Dollars & 330 & 330 & 330 & 330 & \\
\hline $\begin{array}{l}\text { Value of backyard } \\
\text { trees }\end{array}$ & Dollars & 330 & 330 & 330 & 330 & \\
\hline $\begin{array}{l}\text { Number of trees per } \\
\text { acre }\end{array}$ & Number & 87 & 87 & 87 & 87 & \\
\hline $\begin{array}{l}\text { Number of acres } \\
\text { (commercial) }\end{array}$ & Number & 7,400 & 10 & 30 & 90 & 7,530 \\
\hline $\begin{array}{l}\text { Number of } \\
\text { commercial trees }\end{array}$ & Number & 643,800 & 870 & 2,610 & 7,830 & 655,110 \\
\hline $\begin{array}{l}\text { Number of backyard } \\
\text { trees }\end{array}$ & Number & 250,000 & 182,554 & 131,898 & 61,830 & 626,282 \\
\hline $\begin{array}{l}\text { Number of } \\
\text { households }\end{array}$ & Number & $2,398,245$ & $1,751,234$ & $1,265,293$ & 593,136 & $6,007,908$ \\
\hline $\begin{array}{l}\text { Urban avocado tree } \\
\text { density }\end{array}$ & Percent & 10.4 & 10.4 & 10.4 & 10.4 & 10.4 \\
\hline $\begin{array}{l}\text { Total replacement } \\
\text { (commercial trees) }\end{array}$ & Dollars & $212,454,000$ & 287,100 & 861,300 & $2,583,900$ & $216,186,300$ \\
\hline $\begin{array}{l}\text { Total replacement } \\
\text { (backyard trees) }\end{array}$ & Dollars & $82,500,000$ & $60,242,721$ & $43,526,275$ & $20,403,970$ & $206,672,967$ \\
\hline Total & Dollars & $294,954,000$ & $60,529,821$ & $44,387,575$ & $22,987,870$ & $422,859,267$ \\
\hline \multicolumn{7}{|c|}{$\begin{array}{l}\text { * Based on the value of a tree (i.e., the amount of money the tree owner should be compensated for tree loss) as a } \\
\text { structural asset. Farm gate price estimated at } 25 \text { cents per pound. Tree value analysis is located at } \\
\text { https://agecon-trec.ifas.ufl.edu/TreeCostAvocado.htm }\end{array}$} \\
\hline
\end{tabular}

